3L Linguaculture

\title{
NEW YORK, SAN FRANCISCO AND LOS ANGELES: A CULTURAL MAP OF THE BEAT GENERATION
}

\author{
ANDREEA COSMA \\ Ovidius University, Constanta
}

\begin{abstract}
This paper explores the topographical and socio-cultural developments during the Golden Age in New York, Los Angeles and San Francisco, three Beat Generation epicenters, which determined the deconstruction of traditional norms. Modifications at both city and society levels were represented by the emergence of countercultures, such as the Beat. The visibility received by urban problems, due to the increase in social demonstrations and activism, fostered the formation of a unified front that demanded equality and encouraged social and political movements, such as the Civil Rights and the Second Wave Feminism. The socio-political challenges which the American society was confronted with from the 1950s to the 1970s in these three cities, also reveal a few problems regarding the status of the Beats as well as of minorities in metropolises.
\end{abstract}

Keywords: Beat Generation, New York, Los Angeles, San Francisco, space, place, social movements.

\section{INTRODUCTION}

Social movements have taken various shapes and forms in the last seventy years, as people use creativity to express themselves. Art has the power to induce a certain state of mind and to trigger reactions from the public. It can do so by inspiring individuals or by "disturbing" them, because, "art should comfort the 
disturbed and disturb the comfortable," as educational activist César A. Cruz ${ }^{1}$ has claimed. The first section of this essay, "Reconfigurations of the City," follows topographical and socio-cultural developments at mid-twentieth century in New York, Los Angeles and San Francisco, while the second section, "From Beats to Beatniks" looks at the three cities as the epicenters of the Beat Generation writers and as urban spaces of pluralism and multiculturalism. This paper aims to present the environment that led to the formation of the Beat Generation as a cultural movement and to portray the relation between the Beats, space and social activism.

Social phenomena which occur in a city, such as waves of migration, political change and economic restructuring lead to "socio-spatial patterns of development" (Schneider-Sliwa 805). Modifications at both city and society levels had been represented through the emergence of unconventional art and literature which did not only document the blueprint of the after-war urban sphere, but also portrayed the tensions in the metropolis. As Simon Parker notes in his work, Urban Theory and the Urban Experience (2003), the city in the twentieth century is marked by pluralism and diversity in comparison to the eighteenth and nineteenth centuries, rather characterized by oligarchic and elitist societies: "the emphasis on urban ecology (place determines character) has been replaced by an explicit cultural determinism (character determines place)" (78). Each social and cultural group present in the city shapes its space, transforming it into a pluralist environment of many political beliefs, customs and ideologies. Important policy improvements regarding pluralism and multiculturality in America, resulted from the impact of activism and social demonstrations, which took place in the second half of the twentieth century.

\section{RECONFIGURATIONS OF THE CITY}

The poetry published by mid-twentieth century American writers tends to romanticize rural areas, while representations of the city depict an over-crowded, polluted, consumerist space. The period in which writers focused on the city in their poetry marks the transition of prosperous middle-class people, who were relocated from the old towns. While families tended to migrate to the quieter, remote areas outside the city, the post-war economic boom in the United States led to the expansion of cities and the gentrification of the outskirts. Cultural changes that followed the Civil Rights Movement came along with the

${ }^{1}$ César A. Cruz (1974, -) is a gang violence prevention advocate, Cofounder of Homies Empowerment and Dean of Secondary Schools Program at Harvard. His poem, "To Comfort the Disturbed, and to Disturb the Comfortable: Onward Children of the Sun" (1997) is representative for his role as an activist. 
development of the architectural aspect of large cities such as New York. According to Joanne Reitano's The Restless City: A Short History of New York from Colonial Times to the Present (2006), an important moment that led to the massive growth of New York was the settlement of the United Nations and the new urbanization plans due to migration. These were two of the reasons why the growth of the suburbs and the economic boom in the post-war era made New York flourish and led to the construction of new highways and sky-rise buildings (Reitano 156). As Reitano claims, that was the moment when New York became an Empire City considered to be "a World City, which was both a cradle of liberalism and a center of capitalism" (156).

Many sociologists claim that New York is a society characterized by agglomeration and rush and thus people are less tolerant than those living in the Californian cities, like San Francisco and Los Angeles, generally described by writers as easy-going. As Anthony Ashbolt notes in his A Cultural History of the Radical Sixties in the San Francisco Bay Area (2003): "certainly, it is a hell of a lot easier to build a new cultural alternative in California than it is in New York” (29). Just like the sun, most movements rose in the east, but found the space to settle in the west. The Beats were also a group founded in New York that gained prominence in San Francisco, where Lawrence Ferlinghetti laid the foundations of the City Lights Bookstore and Printing House. In City for Sale: The Transformation of San Francisco (1984), Chester Hartman portrays the situation of San Francisco in the 1950s by describing the obstacles which slowed down the development of the city. The office district could not accommodate the migration of corporations in the city and therefore planners had to find solutions for the city's expansion:

\footnotetext{
Expansion westward was impossible: In that direction lay the city's prime retail and hotel area, plus difficult, hilly topography. To the north lay the internally strong residential communities of Chinatown and North Beach and more hills. To the east, the bay limited expansion to the small area occupied by the city's wholesale produce market. If there was to be a substantial increase in the central office district, it would have to be to the south, across 120-foot-wide Market Street, traditionally the city's “Great Divide.” (Hartman 8)
}

Geographical, cultural and economic factors have had a great impact on the way San Francisco has developed to the city it is today. Market Street, which sections the city diagonally, does not only separate the old town from the newer neighborhoods but also serves as a "psychological barrier" (Hartman 8) between the old town and the South of Market (SoMa). As the San Francisco Chronicle notes, before the Great Depression, SoMa was considered the place of “'hobohemia,'-a scruffy but functioning community that served these itinerant workers - [which] sprang up around Fourth and Howard streets” (Kamiya 1). 
There was a significant decrease in the number of businesses in SoMa: "while there were more than 10 billiard parlors South of Market in 1930, by 1940 there were only five, by 1950 three, and by 1960 just one" (Kamiya 10). The "Great Divide" that Hartman mentioned (8), quarantined the low-class community from the rest of San Francisco, making Market Street an isolating wall between the two parts of the city.

San Francisco's developing potential did influence migration from the East Coast to the West Coast of the US, attracting funds and investors: "The Vietnam War and its high-level technology led to an annual influx of billions of federal dollars into the West Coast, stimulating a boom in electronics, aerospace, and related industries" (Hartman 4). With the expansion of war and motion picture industries in California, the west of the US became as economically and socially important to the country as the east. Besides industry and workers relocating to the West Coast, cultural movements also shifted towards the same zone, putting their mark on local culture, which gave great visibility to the arts and to alternative values. In his San Francisco: Portrait of a City 1940-1960 (2014), Fred Lyon depicts his prolonged stay in San Francisco as a photographer: "a quick visit to San Francisco stretched into months" (Lyon 6). His book illustrates San Francisco at mid-century, through photographs that complete the image created by writers:

New York magazine editors would ask me, "Well, what do you have out there?” At least that part was an easy sell. To start, we had our steep hills and iconic cable cars, and our two spectacular bridges. The bay, the fog, distinctive neighborhoods like Chinatown, and one-of-a-kind personalities, like the city's de facto poet laureate, the newspaperman Herb Caen. (Lyon 7)

Herb Caen's newspaper column called the Beat Generation writers "Beatniks," a term that caught on people and made the movement even more popular, although that was not necessarily Caen's initial aim: "Herb Caen's famous invention of the word 'Beatnik,' on April 3, 1958, fell somewhere between patronizing and fascination toward the group that he would banter with for much of the next decade" (Hartlaub 27). The city keeps the essence of the American Frontier alive through its sense of enjoying life and, at the same time, through its multicultural dimension that implies defending one's freedom, culture and territory.

\section{FROM BEATS TO BEATNIKS}

Starting with the 1950s, the focus of the mainstream society on the younger generation increased, due to their involvement in social activism. As Wendy Wall notes in her Inventing the American Way: The Politics of Consensus from 
the New Deal to the Civil Rights Movement (2007), activism was supported by young representatives of various minorities in America: "White ethnics, Black nationalists, Chicano activists, and young Native Americans shunned the unifying language of 'Americanism' that had been embraced by their parents, calling instead for a revival of ethnic, Black, Brown, or Red pride” (288). Embracing their ethnic, cultural and social differences meant redefining social status and thus creating a pluralist society.

As James Burkhart Gilbert notes in A Cycle of Outrage: America's Reaction to the Juvenile Delinquent in the 1950s (1986), these youth movements received negative reactions from the mainstream society that associated such acts with criminal actions: "gradually a new concept of 'subcultures' that stressed the cultural environment of delinquency became more important" (Gilbert 130). Society had been trying to disenfranchise such subcultures while they were only naturally reacting and adapting to social change. Gilbert further states that mainstream society had "mistakenly, and out of larger and incoherent fears of social change, labeled the behavior of youth as criminal” (Gilbert 141). The constant sensation of confusion and revolt against traditional structures of power portray the Golden Age America at the rise of postmodernity, when power is redirected among diverse groups and tradition is attacked by alternative values. The Beat Generation is an important example of postmodernist literature and postmodern experience as its representatives emerged as artists that glorified the underdogs of the society who militated against the previous traditional and conventional writing styles. The Beats "took delight in inferior social and economic positions" (Rogoveanu 248), which separated them from the mainstream goals and thus, put themselves in the position in which they prefer to keep distance from the mainstream society and from the quest of climbing the social ladder. As Megan Reynolds notes in her article "Social Madness in Beat Generation Writing" (2016), the Beats created a space for themselves in New York, Los Angeles and San Francisco by establishing the base of a counterculture: "common meeting places, most notably Greenwich Village, serve to collect outsiders who find comfort in other's similar sentiments" (83). Following the same ideology as that of the Civil Rights Movement at the time, the beats empowered social pariahs through their writing and through the life they chose to promote. Their isolation is both at individual and at community levels, as they feel individually misunderstood and at the same time, they identify themselves as an outsider group from the mainstream society. Megan Reynolds further notes that the "Beat writers, looking to break away from the American norm, found fellowship in the very group of individuals that society at large sought to hide away" (81), not only by accepting their condition but also by embracing a hedonistic lifestyle of pleasure, irrespective of what society considered to be taboo or immoral. 
In his The Beat Generation (2008), Christopher Gair notes that the Beat group "tends to be remembered as a product of and reaction against the stifling conformity of the Eisenhower presidency of the 1950s" (25). The Beats did not only challenge the strict society of the 1940s and the early 1950s, but they also subverted previous literary movements, by bringing innovation to the writing style of poetry and prose. Christopher Gair further notes that one should not overlook the global dimension of the Beat texts due to the multicultural influences it includes (142). The Beats' openness to international culture and toward taboo topics that were still undiscussed at the beginning of the 1950s, such as sex, drugs and homosexuality revolutionized literature and gave people a voice that discussed human experience in all shapes and colors. This style of underground culture that the Beats tackled gave the next generations in the 1960s and 1970s the courage to express themselves and influenced a great number of musicians and artists that shared the same mindset. The Beats' blunt and uncensored attitude in writing and in lifestyle was a fresh view on life for those young people who had witnessed the war: "for the generation of young Britons who had become teenagers in the 1950s, the exotic, romantic landscape portrayed by Jack Kerouac offered a thrilling alternative to a world of rationing and cities still heavily scarred by the German bombs of the Second World War" (Gair 144). The stories of the Beat generation offered readers a taste of what going against authority was like, breaking the rules in a strict society and challenging its mainstream culture.

New York, Los Angeles and San Francisco are considered to be cities of culture and of activism due to their many grass-roots movements that were created. New York is often seen as more rigid and conventional when compared to Los Angeles or San Francisco. New York was often criticized by San Franciscan alternative groups, especially on the topic of music and the kind of music scene Greenwich Village promoted, as emphasized by the Beat poet Kenneth Rexroth, who compared the jazz bands of New York with "all kinds of bums with pawn-shop saxophones put together with scotch tape, and some other guy with something called poetry” (Rexroth in Ashbolt 42). Kenneth Rexroth, one of the most famous poets of the San Francisco Renaissance, considered New York a capitalist place which is characterized by shallowness. On the other hand, he regarded San Francisco as a city with heritage-oriented values: "There wasn't anything like it in San Francisco because we had done the thing in San Francisco...the stuff in New York was ridiculous, and of course it's that whole New York commercial scene. That was all it was for. To make the tourists go to Greenwich Village” (Rexroth in Ashbolt 42). While Rexroth's point of view may have been influenced by his political agenda, New York built the culture of the city as we know it today on its global and cosmopolitan features, despite its 
being more conventional and busier than San Francisco. However, the Beats' work portrays both cities as significant factors in their experience as people and as poets, describing city life in the 1950s in both West and East Coast cities. This blending of experiences from both sides of the country "embodied a conjunction of opposites" (Ashbolt 42) and it reflected on the fact that most Beat members were brought up in New York but spent a considerable time in San Francisco during their adulthood. The mental maps described in the Beats' work serve as the portrayal of Beat experience due to the impact travel had on their life and writing. The cartography they convey becomes representational for the American urban space and for an entire generation that faced the turbulent atmosphere at the middle of the twentieth century.

Kenneth Rexroth was one of the Beats who strongly believed in San Francisco as the cradle of the Beat Generation and who rejected other cities that were considered popular among this group. Rexroth is interchangeably associated with the San Francisco Renaissance and the Beat Generation, contributing to both movements through his poetry and his organized meetings of poets at the Six Gallery in San Francisco. These meetings played an important role in the creation of the hippie movement: "the environmentalism has deep Californian roots dating back to John Muir and the Sierra Club [and] it was also linked to a growing awareness of native American practices and these, in turn, fueled the mysticism (also nurtured strongly by Zen Buddhism)” (Ashbolt 42). San Francisco's high number of Asian immigrants, especially Chinese, has shaped culture, not only in terms of space, such as building the Chinatown in the city, but also in terms of bringing new perspectives about religion and spirituality in the United States.

The Beats' spiritual beliefs were influenced significantly by eastern and Native American practices. These differences from the norms of the 1950s mainstream society were seen by certain groups as delinquency. The American government attempted to take measures on youth delinquency in San Francisco: "Something of an experiment along these lines began in San Francisco in 1943, where courts committed parents to delinquency classes at the San Francisco Parental School when their children were convicted of a crime” (Gilbert 36). People's indignation with San Franciscan youngsters was caused by the fact that they created a lifestyle for themselves that did not correspond with the elders' expectations. Many considered that delinquency was "set against a background of post-war pessimism, anticipation of economic depression and social disruption" (Gilbert 37). This disruption, however, set the tone for a determinate quest for a better, free life. The beat poets were often seen as delinquents, as young rebels that needed to be kept in order. Jennie Skerl discusses this aspect in her book, Reconstructing the Beats (2004) by mentioning the police raids on Beat venues as well as a few of the Beat works that went through censorship 
trials: Ginsberg's Howl and Other Poems (San Francisco, 1956), Burroughs's Naked Lunch (Boston, 1962), Lenore Kandel's The Love Book (San Francisco, 1966) and McClure's The Beard (Berkeley, 1967) [1]. However, San Francisco was more favorable to the Beats, especially the Beat women, who were struggling to carve a space for themselves as female poets or writers in a patriarchal culture. San Francisco's bohemian subculture "provided a space for female subjectivity to claim literary authority" (Skerl 4). Although the Beat men represented an alternative group of people whose values reflected the voice of the marginalized, the Beat women tended to remain outsiders even in this group. Even after more than half a century since the appearance of the Beat subculture, Beat women still lack visibility in the literary space. Beat women paved the way toward women's freedom to pursue careers, arts or unconventional lifestyles. Breaking the barriers imposed by the 1950s, female Beat writers contributed to Second Wave Feminism through their writings and clash with the system. They also helped Beat male writers make ends meet and stick together as a group.

Being in constant search of respite from social obstacles and a sense of belonging, the Beats found a more accepting artistic environment on the opposite coast of the country. California's slower but sure emergence on the American artistic scene in the mid-twentieth century managed to attract individuals whose creativity led to urban regeneration. Groups such as the Beats felt that cities like Los Angeles and San Francisco were more welcoming than the highly capitalist and conventional New York. As John Maynard claims, the bohemian 1960s Venice, Los Angeles, was crucial to the transformation of the neighborhood, attracting various artists who left their mark on the looks of the city, "covering rot and raw brick with color and imagination" (187). John Maynard further notes that Venice became the most "ingeniously painted-on surface in Southern California," not only due to the talented artists of the L.A. Fine Squad, but also due to the way in which the paintings illustrated life in Venice: "Enormous faces grinned from stucco walls and garage door; mobiles and God's-eyes dangles in windows; doors, fences, mailboxes, and railroad tiles alike were covered with birds, rainbows, poems, smart remarks and political symbols” (Maynard 187). California's artistic circles shifted between Los Angeles and San Francisco, making room for underground culture to flourish: "it was not until the late 1960s that a term for art that formed an extension of the "beat" tendency was introduced: Funk" (Delfiner 4). While the term "Funk" had been previously used in connection to jazz, it was later incorporated as a concept in Beat art. In his Art in the San Francisco Bay Area, 1945-1980: An Illustrated History (1985), Thomas Albright describes this type of art as the portrayal of the Beat state of mind: 
A constellation of attitudes and ideas shared by various circles of friends who met in bars and coffee houses and displayed their work in informal, cooperative 'galleries.' These ideas and attitudes found expression in all the arts - painting, sculpture, poetry, music, theater, film - and tended to break down the traditional barriers between them. (82)

Beat meetings fostered a sense of belonging among the group members. The San Francisco Six Gallery served many times as the place of creation, expression and fellowship. Kerouac's The Dharma Bums (1958) depicts Ginsberg's reading of "Howl" as the emergence of the San Francisco Renaissance and as new, complex art projects that unite painting, music and poetry (Delfiner 5). These socalled 'mash-ups' were the group's artistic and political statements. They combined different types of art in order to trigger a cathartic experience.

Lawrence Lipton, a Los Angeles Beatnik and author of The Holy Barbarians (1959) believed that such cultural and artistic formations were responses to social distress: "[I]t is a sign of a crisis in that civilization. If the barbarians come, not with weapons of war but with songs and icons of peace, it is a sign that the crisis is one of a spiritual nature” (Lipton in Maynard 100). It is believed that Lipton saw himself as an older mentor of the young Beats, just as Gertrude Stein was for the Lost Generation (Meares 2). The Beats sheltered their creative meetings in three neighborhoods that later became hubs for Beat fans and hipsters: Greenwich Village in New York, The North Beach in San Francisco and Venice in Los Angeles. Venice West Café and the Gas House were two famous Los Angeles Beat hangouts. The City Lights and the Six Gallery are known for having been frequented by the Beats in San Francisco, while in New York, San Remo and Kettle of Fish hangouts are mentioned in the writers' works. As John Arthur Maynard mentions, The North Beach was the focus of Beat hangouts: "The beat scene was concentrated on Grant Street, a couple of blocks from the City Lights Bookstore. Poetry readings were held regularly at the Bread and Wine Mission, the Coffee Gallery, and the Cellar, which also maintained its own house band to back up the poets” (Maynard 125). Arthur Maynard discloses some of the correspondence between Lipton and Rexroth from late 1952 through 1958, which portrays the strong attachment that each had in relation to the city they lived in. Lawrence Lipton vouched for Los Angeles as the environment of the mid-twentieth century literary renaissance, while Rexroth was in favor of San Francisco, by saying it was "a free and easy city [...] and very hospitable to the artist. Always has been” (Rexroth in Maynard 78). Lipton, on the other hand, considered the Bay a "warmed-over, left-over Greenwich Village" and disagreed that San Francisco was a place that fostered social acceptance, innovative thought and difference: "Only artists are hospitable to new art, and to one another. In Venice, in Los Angeles-'Venice West,' we 
call it—such a community of poets and artists is working...Venice West is to Los Angeles what the Left Bank once was to Paris” (Lipton in Maynard 78). Lipton believes in a strong community of poets that make their voice heard in the society. He argues that society will not create room for new cultures and the Beats would have to force their philosophy against tradition in order to gain visibility.

An example of the Beatniks' fight against the norms is the censorship trial for Allen Ginsberg's Howl and Other Poems (1956), published with the support of Lawrence Ferlinghetti. After City Lights won the trial, the North Beach transformed itself into a place of creation and inspiration for young artists and writers. The Beat movement started shifting from San Francisco to Los Angeles; however, there was not a strong community of Beats to support the movement during its early debut in Venice. The Beat poets in Los Angeles were even more disadvantaged than those in New York and San Francisco due to the locals' lack of interest in the movement. The other two cities remained emblematic as Beat Meccas and eclipsed Venice in this respect. Stuart Perkoff and Lawrence Lipton are among the few Beat writers who put Los Angeles on the Beat map. Both Kenneth Rexroth and Lawrence Lipton are considered to be the "fathers" of the Beats, in the sense that they were the older Beatniks of the group, who contributed at the development of this literary movement and who also initiated a territorial "battle" between the two Californian Beat cities.

The Beats' gatherings had social effects that did not only reflect on the way people entertained themselves and created literature, but also on their political agendas. In his The Making of a Counterculture (1969), sociologist Theodore Roszak associates the message of the Beat Generation works with Charles Wright Mills' Causes of World War III (1957) through the fact that both kinds of writing aim at exposing the true face of America (24). It is further stated that political activism during the post-war period seemed to be the effect of two distinct groups rather than a united common front: "To one side, there is the mind-blown bohemianism of the beats and hippies; to the other, the hard-headed political activism of the student New Left" (Roszak 56). While the first movement seemed to try to escape the American society at the time, the latter sought to confront society and politics. The Beats' lifestyle and writings about seizing the day and the irregularities of the era, together with the new socialist perspectives of young activists, gave visibility to the need for change and managed to influence the institutional and social restructure of the following decades. The Beats' reaction to the conformist and materialistic America was vital to the creation of a later "hip" mindset that translated into a more liberal and inclusive mainstream attitude. The writings of the Beat Generation represent 
both their attempt to distance themselves from the mainstream societal norms and their cry against the society's restrictive expectations from them.

\section{CONCLUSION}

The post-war era could be looked at as a multi-layered site of a struggle. It may refer to the physical, built-in spaces due to the segregation issues at the time, as Greenwich Village, Venice and the North Beach are examples of how physical spaces can become representations of cultural values and of experience. Moreover, Harlem, Skid Row and SoMa are examples of neighborhoods which show that the trespassing of physical space can reflect the social tensions of the era and, at the same time, emphasize the oppression undergone by the discriminated groups. The second half of the twentieth century presents various markers of social development everywhere in the US and especially in large metropolises such as New York, Los Angeles and San Francisco, where the ruling authority was constantly under the pressure of movements and demonstrations to issue policies and to aid those with fewer opportunities to reach a consensus among the diverse communities that made up the city. These three metropolises are often seen as examples of free cities, which portray the American "bastion of liberalism and progressive thought" (Latour xiv) due to the social and multicultural diversity of people that they host, as well as due to the ongoing struggle for consensus between the authority and minority.

Although the Beat Generation was seen as a delinquent group at the time, the impact it created did not only influence youth culture and literature after the 1950s, but it also encouraged social development, including the Civil Rights Movement and Second Wave Feminism, by challenging America's traditional values. Their cultural involvement in the three American cities, New York, San Francisco, and Los Angeles did not only lead to a national literary and artistic renaissance but also to urban regeneration, as the Beats' unconventional lifestyle and work paved the way toward a "hip" movement that manifested itself in terms of both culture and spatial organization. The influence that the Beat generation had on Greenwich Village, Venice and the North Beach, transformed the three neighborhoods into touristic destinations, as more and more Beatniks wanted to experience what the Beats' life was. Moreover, the culture created around the Beat venues emphasized an atmosphere of rebellion, combined with a sense of belonging to a certain community that fostered new philosophical, religious and literary ideas in an already changing society. 


\section{Works Cited}

Albright, Thomas. Art in the San Francisco Bay Area, 1945-1980: An Illustrated History. Los Angeles: University of California Press, 1985.

Ashbolt, Anthony. A Cultural History of the Radical Sixties in the San Francisco Bay Area. New York: Routledge, 2016.

Delfiner, Judith. “The Art of California Counter-Culture in the 1950s.” Perspective, no. 2, 2015, pp. 1-17.

Gair, Christopher. The Beat Generation. Oxford: Oneworld Publications, 2008.

Gilbert, James Burkhart. A Cycle of Outrage: America's Reaction to the Juvenile Delinquent in the 1950s. New York: Oxford University Press, 1986.

Hartlaub, Peter. "How the Beats Helped Build San Francisco's Progressive Future.” San Francisco Chronicle, 1 Jan. 2015.

Hartman, Chester. City for Sale: The Transformation of San Francisco. Berkeley: University of California Press, 2002.

Kamiya, Gary. "SF 'Hobohemia' Transformed into Skid Row as Jobs and City Changed.” San Francisco Chronicle, 10 Aug. 2019, https://www.sfchronicle.com/chronicle_vault/article/SF-hobohemiatransformed-into-Skid-Row-as-14294228.php

Latour, Jane. Sisters in the Brotherhoods: Working Women Organizing for Equality in New York City. New York: Palgrave Macmillan, 2009.

Lyon, Fred. San Francisco: Portrait of a City 1940-1960. New York: Princeton Architectural Press, 2014.

Maynard, John Arthur. Venice West: The Beat Generation in Southern California. London: Rutgers University Press, 1991.

Meares, Hadley. "Lawrence Lipton and Venice, California's Claim to Beat Fame.” KCET, 9 Oct. 2020. www.kcet.org/shows/lost-la/lawrence-lipton-and-venicecalifornias-claim-to-beat-fame. Accessed on 26 Dec. 2020.

Parker, Simon. Urban Theory and the Urban Experience: Encountering the City. New York: Routledge, 2015.

Reitano, Joanne R. The Restless City: A Short History of New York from Colonial Times to the Present. New York: Routledge, 2006.

Reynolds, Megan, "Social Madness in Beat Generation Writing.” The Expositor, no. 6, 2016, pp. 80-99.

Rogoveanu, Raluca. "Glancing at Deforming Mirrors: The Mad Artists of the Beat Generation.” Analele Universităţii Ovidius din Constanţa, Seria Filologie, no. 20, 2009, pp. 247-252.

Roszak, Theodore. The Making of a Counter Culture: Reflections on the Technocratic Society and Its Youthful Opposition. New York: Doubleday \& Company, Inc, 1969.

Schneider-Sliwa, Rita. "Urban Geography.” International Encyclopedia of the Social \& Behavioral Sciences, eds. Neil J. Smelser and Paul B. Baltes. Berlin: Elsevier Science Ltd 2001, pp. 801-806.

Skerl, Jennie. Reconstructing the Beats. New York: Palgrave Macmillan, 2009. 
Wall, Wendy. Inventing the American Way: The Politics of Consensus from the New Deal to the Civil Rights Movement. New York: Oxford University Press, 2009.

\section{BIONOTE}

Andreea Cosma is a $\mathrm{PhD}$ student of Philology at Ovidius University Constanta, conducting research in geocritical readings of, and activist manifestations in, the literary works of the Beat writers under the supervision of Professor Adina Ciugureanu, PhD. Andreea Cosma has a BA in American Studies and an MA in Anglo-American Studies, both at Ovidius University. She is also an alumna of the SUSI program, Global Social Entrepreneurship Institute. Her most recent works are "Beat City: 'Metamanifest Places' at the Crossroads of Literature and Activism in the Beat Generation” (2019), published in The International Journal of Cross-Cultural Studies and Environmental Communication and "The Poet as Activist: Spaces of Protest in Allen Ginsberg's Poetry" (2020), published in The Annals of 'Ovidius' University of Constanța: Philology Series. E-mail: cosma.andr@gmail.com 